\title{
Periodontal disease and dental caries from Krapina Neanderthal to contemporary man - skeletal studies
}

\author{
Berislav Topić1, Hajrija Raščić-Konjhodžić ${ }^{2}$ Mojca Čižek Sajko ${ }^{3}$
}

\author{
${ }^{1}$ Academy of Sciences and Arts \\ of Bosnia and Herzegovina, Sarajevo \\ Bosnia and Herzegovina \\ ${ }^{2}$ Faculty of Stomatology, University \\ of Sarajevo, Sarajevo, Bosnia and \\ Herzegovina \\ ${ }^{3}$ Institute for Biostatistics and Medical \\ Informatics, Faculty of Medicine \\ Ljubljana, Slovenia \\ Corresponding author: \\ Berislav Topić \\ Academy of Sciences and Arts \\ of Bosnia and Herzegovina \\ 71000 Sarajevo \\ Bosnia and Herzegovina \\ btopic@anubih.ba \\ Tel: + 38733560700 \\ Fax: + 38733560703
}

Received: 20 May 2011

Accepted: 9 February 2012

Copyright (c) 2012 by

Academy of Sciences and Arts of Bosnia and Herzegovina. E-mail for permission to publish: amabih@anubih.ba

\begin{abstract}
Objective. The aim of this study was the quantification of alveolar bone resorption as well as the number and percentage of teeth with dental caries. Materials and Methods. Four samples of jaws and single teeth were studied from four time periods, i.e. from the Krapina Neanderthals (KN) who reportedly lived over 130,000 years ago, and groups of humans from the $1^{\text {st }}, 10^{\text {th }}$ and $20^{\text {th }}$ centuries. Resorption of the alveolar bone of the jaws was quantified by the tooth-cervicalheight $(\mathrm{TCH})$ index. Diagnosis of dental caries was made by inspection and with a dental probe. TCH-index was calculated for a total of 1097 teeth from 135 jaws. Decay was calculated for a total of 3579 teeth. Results. Resorptive changes of the alveolar bone in $\mathrm{KN}$ and $1^{\text {st }}$ century man were more pronounced on the vestibular surface than interdentally $(\mathrm{p}<0.05)$, while no significant difference could be confirmed for $10^{\text {th }}$ and $20^{\text {th }}$ century man $(\mathrm{p}=0.1)$. The number (percentage) of decayed teeth was $0(0 \%, \mathrm{n}=281$ teeth) in $\mathrm{KN}, 15(1.7 \%$; $\mathrm{n}=860$ teeth) in $1^{\text {st }}$ century, $24(3.4 \% ; \mathrm{n}=697$ teeth $)$ in $10^{\text {th }}$ century, and 207 $\left(11.9 \%, \mathrm{n}=1741\right.$ teeth) in $20^{\text {th }}$ century. Conclusion. On the basis of our results it may be postulated that in contemporary man in relation to $\mathrm{KN}$, the accumulation of plaque pathogens in the interdental space is substantially greater than on the vestibular side. These findings have practical, educational and preventive value for oral hygiene improvement, especially of the interdental space, which should help decrease the prevalence of periodontal disease and dental caries, and improve oral as well as general health.
\end{abstract}

Key words: Periodontium, Alveolar resorption, Neanderthal, TCHindex, Dental caries.

\section{Introduction}

The hominids are zoological groups who had some characteristics of Homo sapiens. Hillson (1) describes the family Hominidae (Table 1).

Paleoanthropological and archeological materials have been frequently used in medicine, not only because they can help us understand a biomedical problem of human nature, but also because they are convenient for investigation. Paleoanthropology and archeology are fields of high interest for many branches of science, dentistry being no exception, in fact dentistry has special interest in mutual collaboration. A general survey 
Table 1 The family Hominidae (1)

\begin{tabular}{llll}
\hline Species & Sites & Stratigraphic division & Date ranges \\
\hline Australopithecines & & & \\
\hline Ardipithecus ramidus & East Africa & Pliocene & c. 4.4 Ma BP \\
Australopithecus anamensis & East Africa & Pliocene & $4.2-3.9 \mathrm{Ma} \mathrm{BP}$ \\
Australopithecus afarensis & East Africa & Pliocene & $3.75-2.8 \mathrm{Ma} \mathrm{BP}$ \\
Australopithecus africanus & South Africa & Pliocene & $3-2.5 \mathrm{Ma} \mathrm{BP}$ \\
Paranthropus robustus & South Africa & Lower Pleistocene & $1.8-1.5 \mathrm{Ma} \mathrm{BP}$ \\
Paranthropus boisei & East Africa & Pliocene, Lower Pleistocene e & C. 2.6-1.2 Ma BP \\
\hline Hominines & & & \\
\hline Homo habilis & Africa (+ ?) & Pliocene, Lower Pleistocene & $2.2-1.6 \mathrm{Ma} \mathrm{BP}$ \\
Homo erectus & Asia & Middle Pleistocene & 700-125 ka BP (1.9 Ma \\
Homo sapiens (archaic) & (+ Africa earlier dates) & BPm 1.6 Ma BP) \\
Homo sapiens (Neanderthal) & Africa + Europe & Middle Pleistocene & $700-125 \mathrm{ka} \mathrm{BP}$ \\
$\begin{array}{l}\text { Homo sapiens } \\
\text { (anatomically modern) }\end{array}$ & Europe + West Asia & Upper Pleistocene & $100-35 \mathrm{ka} \mathrm{BP}$ \\
\hline
\end{tabular}

BP - years before present; Ma - millions of years; ka - thousands of years; Holocene - 10 ka BP - present; Pleistocene - 2 Ma-10ka BP; Pliocene - 5,1 Ma-2 Ma BP.

of dental variability in human groups would be incomplete without some consideration of pathologic differences. These may reflect variations in the genetic, dietary, bacteriologic and physiologic aspects of man's development.

Two major problems in dentistry, i.e. periodontal disease and dental caries (decay), can be thoroughly examined by use of paleoanthropological and archeological materials. There are more literature data on decay than on periodontal disease in the past in the human race $(2,3)$. This is so because caries lesions have been preserved on skeletons from the very beginning of their occurrence, whereas the only evidence for periodontal disease is when the pathologic events involve the calcified periodontal structure (alveolar bone and cementum).

In this study there were two aims: First, the loss of alveolar bone was assessed by the tooth-cervical height index (TCH-index) on the vestibular and interdental side of the alveolus (4) in Krapina Neanderthals (KN) who lived 130,000 years ago (5), and in groups of contemporary humans from the $1^{\text {st }}, 10^{\text {th }}$ and $20^{\text {th }}$ centuries, and second, the number and percentage of caries lesions on all samples of teeth in these four groups was diagnosed.

\section{Material and methods}

For alveolar bone resorption, all samples of jaws, except for $\mathrm{KN}$, were subdivided into two age groups: $20-29$ and $>50$ years. This grouping was not applicable in the $\mathrm{KN}$ group, as none of $\mathrm{KN}$ individuals was older than 23 years at the time of death.

\section{Group 1 - KN}

The alveolar bone included $54 \mathrm{KN}$ teeth, i.e. 10 teeth from three maxillae and 44 teeth from six mandibles. Examples of a $\mathrm{KN}$ maxilla and a KN mandible are presented in Figures 1 and 2 .

The age of the KNs whose jaws were examined was reported to be $14-23$ years. Caries lesions included 281 teeth, 91 belong- 

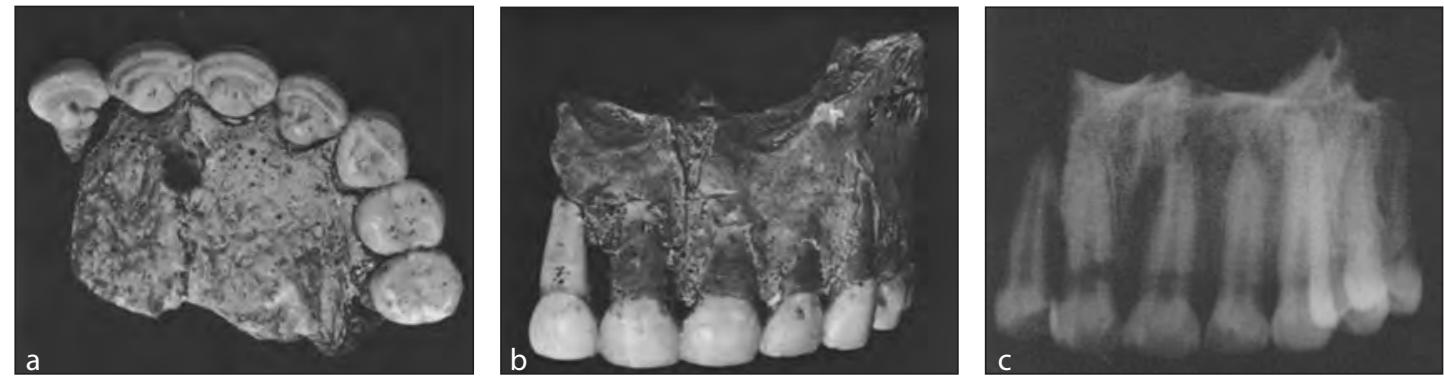

Figure 1 Maxilla of Krapina Neanderthal $(6,7)$ : a - occlusal aspect; b - vestibular aspect; c - radiographic image.
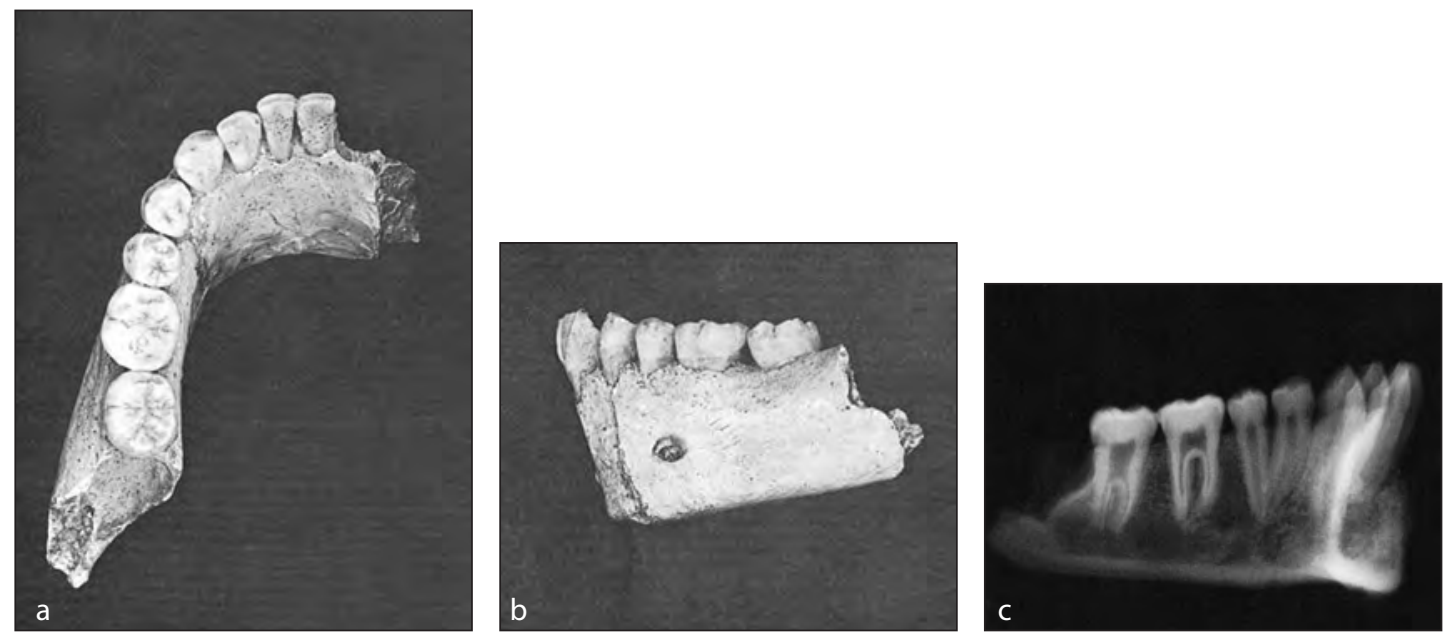

Figure 2 Mandible of Krapina Neanderthal No. 55 (6, 7): a - occlusal aspect; b - vestibular aspect; c - radiographic image.

ing to the jaws, and 190 teeth were outside the jaws, as a single tooth. The age of the KNs whose teeth were checked was $3-27$ years. These jaws and teeth are in the possession of the Natural History Museum in Zagreb, Croatia.

\section{Group 2 - Contemporary humans from the $1^{\text {st }}$ century}

The alveolar bones included teeth belonging to human skulls from the $1^{\text {st }}$ century, divided into two subgroups according to age:

- 20-29 age subgroup of 14 skulls with 28 jaws and 295 teeth, and

- >50 age subgroup of 8 skulls with 16 jaws and 94 teeth.
Caries lesions included 860 teeth which belonged to the $1^{\text {st }}$ century jaws.

\section{Group 3 - Contemporary humans from the $10^{\text {th }}$ century}

The alveolar bones included teeth belonging to human skulls of the $10^{\text {th }}$ century, also divided into subgroups according to age:

- 20-29 age subgroup of 8 skulls with 16 jaws and 135 teeth, and

- >50 age subgroup of 6 skulls with 12 jaws and 60 teeth.

Caries lesions included 697 teeth belonging to the $10^{\text {th }}$ century jaws.

The skulls from the $1^{\text {st }}$ and $10^{\text {th }}$ century belong to the National Museum in Sarajevo, Bosnia and Herzegovina. 

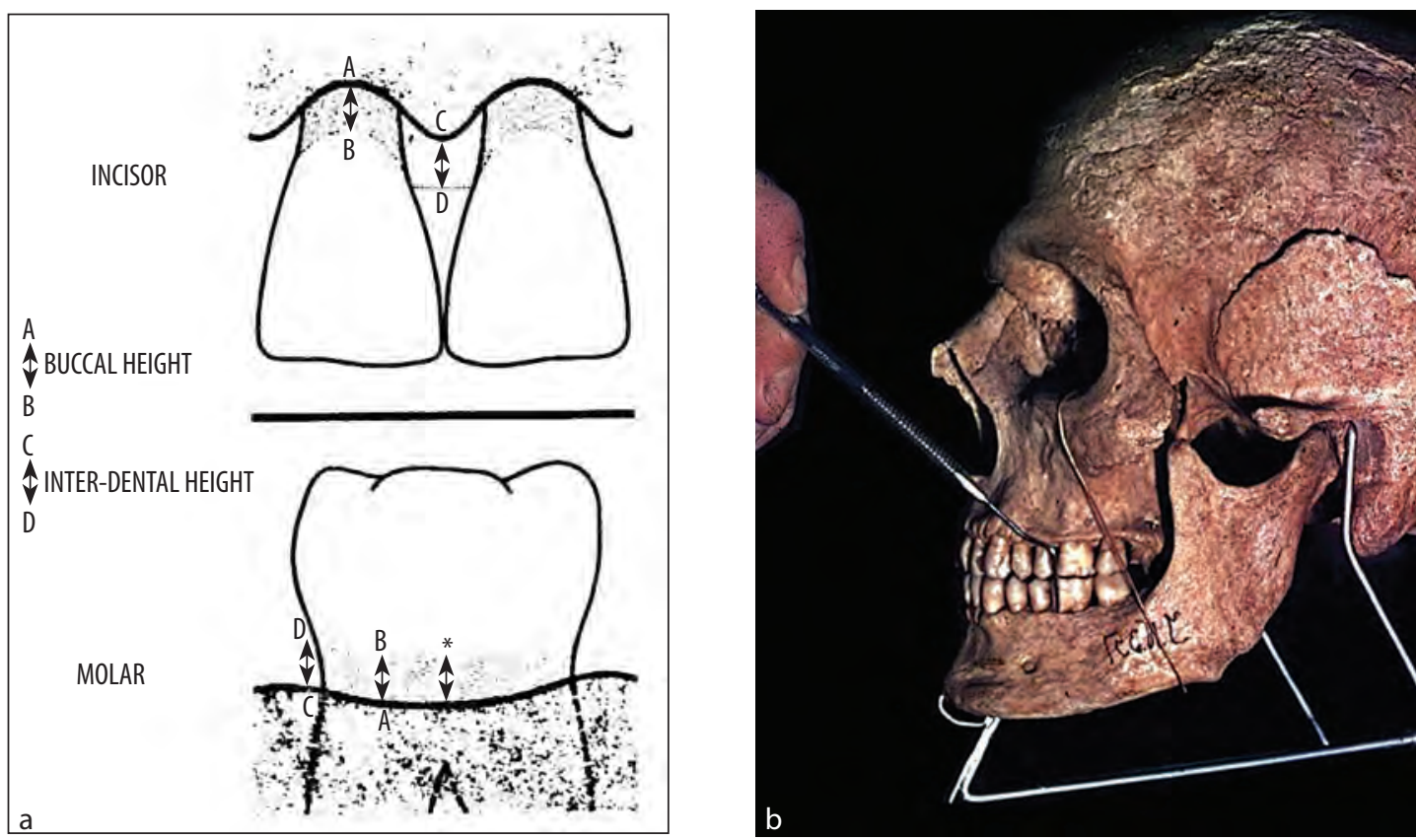

Figure 3 Measurement of Tooth Cervical Height (TCH-index). (a) Vestibular TCH - mean distance between A (at alveolar crest) and B (at cementoenamel junction) per all teeth in the jaw; interdental TCH - mean distance between C (at alveolar crest) and D (at cementoenamel junction) per all teeth in the jaw (figure from Davies et al. (4). Buccal height - vestibular height. (b) Measuring alveolar bone resorption with periodontal probe.

\section{Group 4 - Contemporary humans from the $20^{\text {th }}$ century}

The alveolar bones included teeth belonging to human skulls from the $20^{\text {th }}$ century, divided into two subgroups:

- 20-29 age subgroup of 13 skulls with 26 jaws and 281 teeth, and

- >50 age subgroup of 18 skulls with 36 jaws and 178 teeth.

Caries lesions included 1741 teeth belonging to the $20^{\text {th }}$ century jaws.

The skulls from the $20^{\text {th }}$ century belong to the Institute of Anatomy, School of Medicine, University of Sarajevo, Bosnia and Herzegovina. The age of the skulls from the $1^{\text {st }}$ and $10^{\text {th }}$ centuries was determined by the Vallois method (8). This method is based on measurements of the obliteration of the suture skulls. The resorption of the alveolar bone was measured by the TCH-index according to Davies et al. (4), using a compass and a periodontal probe. $\mathrm{TCH}$-index was defined as the mean distance from the cementoenamel junction to the alveolar crest measured per all teeth in the jaw (Figure 3). The measurement was done on two sides, vestibular and interdental and expressed in millimeters, with a precision of $0.5 \mathrm{~mm}$. Diagnosis of caries lesion was done by inspection and with a dental probe by a single evaluator.

\section{Statistical analysis}

Data are presented as mean and standard deviation (SD) and as proportions if they are nominal. Comparisons between mean vestibular and interdental $\mathrm{TCH}$-index were done using paired t-tests, while comparisons of the mean TCH-index between study groups were done using unpaired t-tests or one-way analysis of variance. The relation between the mean vestibular and interdental $\mathrm{TCH}$-index was expressed as the $\mathrm{V} / \mathrm{I}$ or I/V ratio and its $95 \%$ confidence interval (CI). 
For dental caries, differences between observed and expected frequencies in the four study groups were analysed by the $\chi^{2}$ test, followed by post-hoc comparisons with the Keppel modification of the Bonferroni correction of type I error. The level of significance was defined as $p<0.05$. Statistical analysis was performed using the $\mathrm{R}$ language for statistical computing (9).

\section{Results}

The results for alveolar bone resorption assessed as mean $\mathrm{TCH}$-index are given in Table 2.

Comparison of the mean $\mathrm{TCH}$-index between the vestibular and interdental tooth sides shows that there is a significantly greater resorption of alveolar bone vestibularly than interdentally in the $\mathrm{KN}$ group $(\mathrm{p}=0.001)$ and also in the $1^{\text {st }}$ century group ( $\mathrm{p}=0.001$ or $\mathrm{p}=0.05$ ). On the other hand, no statistically significant difference could be confirmed between the vestibular
$\mathrm{TCH}$-index and the interdental $\mathrm{TCH}$-index in contemporary man from the $10^{\text {th }}$ and $20^{\text {th }}$ century groups $(\mathrm{p}=0.1)$. Results expressed as a $\mathrm{V} / \mathrm{I}$ ratio show that in the subgroup of $>50$ year old contemporary man of the $20^{\text {th }}$ century the interdental resorption is almost equal to the vestibular resorption $(\mathrm{V} / \mathrm{I}=1.06$, 95\% CI: 1.03, 1.10). Changes in interdental resorption increase in contemporary man in the subgroups of $>50$ years old $(\mathrm{p}<0.001)$, and its increase from $\mathrm{KN}$ to $20^{\text {th }}$ century is almost two-fold (1.94, $\mathrm{p}<0.001)$.

Interdental and vestibular values of $\mathrm{TCH}$-index for $\mathrm{KN}$ were taken as reference values and expressed as $100 \%$ (Table 3 ).

For the other three study groups, the interdental and vestibular $\mathrm{TCH}$-index was calculated in respect to the $\mathrm{KN}$ reference and expressed as a percentage. Dynamics of interdental resorption was already higher in the subgroup of $>50$ years old from the $10^{\text {th }}$ century (123.3\%), while in the subgroup of $>50$ years old from the $20^{\text {th }}$ century the interdental resorption is almost twice as high

Table 2 Mean TCH-index and vestibular-interdental ratio (V/I) values according to the study group (KN, $1^{\text {st }}, 10^{\text {th }}$ and $20^{\text {th }}$ century)

\begin{tabular}{|c|c|c|c|c|c|c|}
\hline Study group & $\begin{array}{l}\text { No. } \\
\text { of jaws }\end{array}$ & $\begin{array}{l}\text { No. } \\
\text { of teeth }\end{array}$ & $\begin{array}{l}\text { Vestibular TCH, } \\
\text { mean (SD) }\end{array}$ & $\begin{array}{l}\text { Interdental TCH, } \\
\text { mean (SD) }\end{array}$ & $p$-value ${ }^{1}$ & $\begin{array}{l}\text { V/I ratio } \\
(95 \% \mathrm{Cl})\end{array}$ \\
\hline \multicolumn{7}{|l|}{ KN (14-23 years) } \\
\hline Maxilla & 3 & 10 & $8.15(1.36)$ & $2.10(0.22)$ & 0.01 & - \\
\hline Mandible & 6 & 44 & $5.33(0.46)$ & $2.68(0.21)$ & 0.001 & - \\
\hline Total & 9 & 54 & $6.12(0.44)$ & $2.57(0.17)$ & 0.001 & $2.38(2.32,2.45)$ \\
\hline \multicolumn{7}{|l|}{$1^{\text {st }}$ century } \\
\hline 20-29 years & 28 & 295 & $2.80(0.29)$ & $1.79(0.10)$ & 0.001 & $1.56(1.54,1.59)$ \\
\hline$>50$ years & 16 & 94 & $4.36(1.17)$ & $2.34(0.22)$ & 0.05 & $1.86(1.76,1.97)$ \\
\hline \multicolumn{7}{|l|}{$10^{\text {th }}$ century } \\
\hline 20-29 years & 12 & $\begin{array}{l}135 \\
60\end{array}$ & $2.50(0.28)$ & $1.82(0.38)$ & 0.1 & $1.37(1.32,1.43)$ \\
\hline$>50$ years & 8 & & $3.78(0.32)$ & $3.17(0.44)$ & 0.1 & $1.19(1.14,1.24)$ \\
\hline \multicolumn{7}{|l|}{$20^{\text {th }}$ century } \\
\hline $20-29$ years & 26 & 281 & $3.67(0.17)$ & $2.99(0.17)$ & 0.1 & $1.23(1.22,1.24)$ \\
\hline$>50$ years & 36 & 178 & $5.31(0.95)$ & $4.99(0.73)$ & 0.1 & $1.06(1.03,1.10)$ \\
\hline
\end{tabular}

'p-values derived from a paired t-test comparing vestibular and interdental TCH-index. $\mathrm{Cl}$ - confidence interval; $\mathrm{KN}$ - Krapina Neanderthals; SD - standard deviation; $\mathrm{TCH}$ - tooth-cervical height index. 
Table 3 Percentual TCH-index and interdental-vestibular ratio (I/V) values according to the study group (KN, $1^{\text {st }}, 10^{\text {th }}$ and $20^{\text {th }}$ century)

\begin{tabular}{lllll}
\hline Study group & Age subgroup & Interdental $\mathrm{TCH},(\%)$ & Vestibular $\mathrm{TCH},(\%)$ & $\mathrm{I} / \mathrm{V}$ ratio $(95 \% \mathrm{Cl})$ \\
\hline $\mathrm{KN}$ & $14-23$ & 100.0 & 100.0 & 1.00 \\
\hline 1st century & $20-29$ & 69.6 & 45.8 & $1.52(1.51,1.53)$ \\
\hline & $>50$ & 91.1 & 71.2 & $1.28(1.24,1.32)$ \\
\hline 10th century & $20-29$ & 70.8 & 40.8 & $1.74(1.71,1.75)$ \\
\hline & $>50$ & 123.3 & 61.8 & $2.00(1.98,2.02)$ \\
\hline 20th century & $20-29$ & 116.3 & 60.0 & $1.94(1.93,1.95)$ \\
\hline & $>50$ & 194.2 & 86.8 & $2.24(2.23,2.25)$ \\
\hline
\end{tabular}

$\mathrm{Cl}$ - confidence interval; KN - Krapina Neanderthals; TCH - tooth-cervical height index.

Table 4 Dental caries according to the study group $\left(\mathrm{KN}, 1^{\text {st }}, 10^{\text {th }}\right.$ and $20^{\text {th }}$ century), for all age groups together

\begin{tabular}{lll}
\hline Study group & Number of teeth examined & Number (\%) of teeth with caries \\
\hline $\mathrm{KN}$ & 281 & $0(0.0)$ \\
$1^{\text {st }}$ century & 860 & $15(1.7)$ \\
$10^{\text {th }}$ century & 697 & $24(3.4)$ \\
$20^{\text {th }}$ century & 1741 & $207(11.9)$ \\
\hline
\end{tabular}

KN - Krapina Neanderthals

(194.2\%) in respect to the $\mathrm{KN}$, whereas vestibular resorption in contemporary humans did not reach the resorption values of $\mathrm{KN}$. Results for caries lesions are shown in Table 4.

The proportion of decay varied significantly between the study groups $(\mathrm{p}<0.001)$. In teeth from the $1^{\text {st }}$ century, the proportion of caries lesions was significantly higher than in $\mathrm{KN}$ teeth $(1.7 \%$ vs. $0 \%, \mathrm{p}=0.029)$, while the highest proportion of decay was observed in teeth from the $20^{\text {th }}$ century $(11.9 \%$ vs. $0 \%, \mathrm{p}<0.001)$.

\section{Discussion}

The first skeletal remains, after which the Neanderthal hominid was named, were found in 1856 in Neanderthal, a valley in Germany. In 1899, the first remains of Neanderthal hominids were found by Dragutin Kramberger-Gorjanović in Krapina, Croatia. Krapina is a town in the north-west Croatia, some $60 \mathrm{~km}$ from Zagreb. Most recent studies on tooth enamel (electron spin reso- nance) ESR showed that KN lived 130,000 years ago (5). The Krapina diluvium collection contains about 900 bone remains of $\mathrm{KN}$. A very important segment of this collection are the remains of 281 teeth (190 single teeth and 91 teeth still attached to the alveolar bone). These measurements were made on 54 attached teeth aged $\geq 14$ years where the alveolar bones were not destroyed post mortem.

All skeletons were aged between 3 and 27 years. Alveolar resorption was examined on the jaws belonging to the 14-23 years group. This is why the groups from the $1^{\text {st }}, 10^{\text {th }}$ and $20^{\text {th }}$ century are divided into two age subgroups of 20-29 and $>50$ years each. Considering the $\mathrm{KN}$ life expectancy of 23 years, it may have been more prudent to compare $\mathrm{KN}$ with the $>50$ age group of contemporary man. The samples of jaws from KN, $1^{\text {st }}$ and $10^{\text {th }}$ centuries were accidental rather than representative or stratified. All skulls from the $1^{\text {st }}, 10^{\text {th }}$ and $20^{\text {th }}$ centuries had both jaws well preserved. 
The results of the $\mathrm{TCH}$-index for the $1^{\text {st }}$, $10^{\text {th }}$ and $20^{\text {th }}$ century humans showed the alveolar resorption to be greater on the interdental septum and smaller on the vestibular side, as compared with $\mathrm{KN}$. The vestibular to interdental resorption ratio expressed as a factor ranged from 2.38 in $\mathrm{KN}$ to 1.23 in the 20-29 year group or 1.06 in the age group of $>50$ years in the $20^{\text {th }}$ century jaws (Table 2 ). If the interdental vs. vestibular values are expressed as $100 \%$, then the interdental to vestibular (I/V) factor $\mathrm{KN}$ expressed as a factor is 1.00. The factor was $1.52,1.74$ and 1.94 for the 20-29 year group, and 1.28, 2.00 and 2.24 for the $>50$ year group from the $1^{\text {st }}, 10^{\text {th }}$ and $20^{\text {th }}$ centuries, respectively (Table 3 ).

What do these results imply? Without the presence of the gingiva, it is possible to determine to the nearest millimeter the amount of bone loss from the cementoenamel junction tothe alveolar crest much more easily than it is possible in patients. Various methods have been proposed for recording the amount of alveolar bone loss in skeletal material by measuring the distance from the cementoenamel junction to the alveolar crest for each tooth and averaging them for the arch, arch quadrant, or individual $(4,10,11)$.

The loss of alveolar bone by resorption is the critical event in the pathogenesis of periodontal disease. Bone resorption is a complex process that is morphologically manifested by erosion of the bone surface (Howship's lacunes) and large multinuclear cells, osteoclasts. Another mechanism of bone resorption is the formation of an acidosis environment, leading to dissolution of the bone constituent minerals. The mediators of bone resorption include prostaglandins, osteoclast activating factor (OAF), lipopolysaccharides (LPS), complement system, interleukins (IL-1, IL-3, IL-6), parathormone (PTH), macrophage colony stimulating factor (M-CSF), tumor necrosis factor alpha
(TNF-alpha), tumor necrosis factor beta (TNF-beta) and vitamin D-3 (12).

Severson et al. (13) demonstrated on human autopsy material that the cell count in the osteogenic part of the periodontium decreased with age. Sarajlić et al. (14) showed that the process of alveolar resorption on the labial aspect of anterior monoradicular 845 teeth from 198 male bodies aged 23-69 years at death, increased with age.

We did not study the morphological relationship of proximal areas in any of the four groups. The results confirmed the wellknown opinion on plaque retention to be greater in the interdental space than on the vestibular side

Löe et al. (15) proved that plaque was the initial etiopathological agent for the onset of gingivitis, as known from Müller's theory of decay.

Mandel (16) divides the history of periodontology into a number of eras:

- era of calculus (from Hippocrates to 1955.) and after

- era of plaque

- era of host response

- era of bacterial specificity

- era of host - bacterium interaction

- era of transition

- era of regulation and

- era of genetics.

There are several hypotheses on the role of plaque in the etiology of gingivitis:

- non-specific plaque hypothesis

- specific plaque hypothesis and

- opportunistic plaque hypothesis.

Plaque quantification according to teeth area was investigation by Lang (17). He found the highest plaque accumulation on the distal side of molars, followed by premolars and canine, and least on incisors. The lower distal surfaces of the teeth were more severely involved than the upper ones.

Plaqueology is a new field of dentistry, established in 1969, dealing with the origin, 
development, structure, bacteriology, biochemistry, immunology, control and prevention of plaque (18). During evolution, the composition of plaque and its quantity have been changing, particularly in the interdental area, as also demonstrated in the present study. The recognition of the increasing rate of interdental alveolar bone resorption during the evolution of man has a practical, educational as well as preventive value for oral hygiene improvement and in the struggle against periodontal disease and decay. In 1998, a symposium on interdental space hygiene was held in Florence, Italy $(17,19-23)$. The papers presented were focused on the role of patient cooperation, including knowledge, skills, willingness, information - cognitive, instruction - psychomotor, motivation - affective, methods and techniques.

The method of the TCH index (4) used in the study is based on linear measurements taken from a fixed point of the cementoenamel junction to the alveolar bone margin, and this measurement was equated with inflammatory bone loss $(10,24-27)$. The method should be additionally controlled in groups or individuals with severe occlusal attrition, as compensatory tooth eruption has been shown to have likely occurred in such a condition $(28,29-32)$. This subsequent tooth eruption appears to be compensation for the lost tooth height and an attempt to maintain vertical dimension of the masticator apparatus. Attrition was not examined in the present study, so it could not be related to compensatory tooth eruption and root exposure.

In the 20-29 year groups, the values of the $\mathrm{TCH}$-index on the vestibular side were slightly lower in the $10^{\text {th }}$ than in the $1^{\text {st }}$ century sample. The difference was not statistically significant (Table 2). The values of $\mathrm{TCH}$-index obtained in the $20^{\text {th }}$ century sample were significantly higher than those recorded in the $1^{\text {st }}$ and $10^{\text {th }}$ century samples, indicating that periodontal disease and dental caries have an increasing trend in modern man.

The results of this study for teeth caries are shown in Table 4. Decay was not diagnosed on KN teeth whereas on teeth samples from the $1^{\text {st }}, 10^{\text {th }}$ and $20^{\text {th }}$ centuries it is

Table 5 Dental caries in some earlier human population (adults only) (33)

\begin{tabular}{lllll}
\hline Time & Series & Author & $\begin{array}{l}\text { Number of } \\
\text { teeth examined }\end{array}$ & $\begin{array}{l}\text { Number (\%) of teeth } \\
\text { with caries }\end{array}$ \\
\hline $\begin{array}{l}70.000- \\
35,000 \text { B.C. }\end{array}$ & $\begin{array}{l}\text { European } \\
\text { Neanderthal }\end{array}$ & Brothwell & 259 & $0(0.0)$ \\
\hline $\begin{array}{l}35,000- \\
10,000 \text { B.C }\end{array}$ & $\begin{array}{l}\text { M. Carmel } \\
\text { (Skhul) }\end{array}$ & Brothwell & 523 & $5(1.0)$ \\
\hline & French Neolitic & Hartweg (1945) & 11717 & $379(3.2)$ \\
& German Neolitic & Brinch (1949) & 1589 & $27(1.8)$ \\
& Swedish Neolitic & Holmer (1956) & 6402 & $91(1.4)$ \\
$3,000-$ & Danish Neolitic & Pedersen (1939) & 3612 & $56(1.2)$ \\
1,000 B.C. & British Neolitic & Brothwell (1962) & 1151 & $36(3.1)$ \\
& Predinastic & Brothwell (1963) & 1742 & $40(2.3)$ \\
& Egyptian & Mao Yen (1959) & 884 & $38(4.3)$ \\
\hline 3,000- & China & & 27879 & $674(2.4)$ \\
\hline 1,000 B.C. & Total: & & & \\
\hline
\end{tabular}

B.C. - Before Christ. 


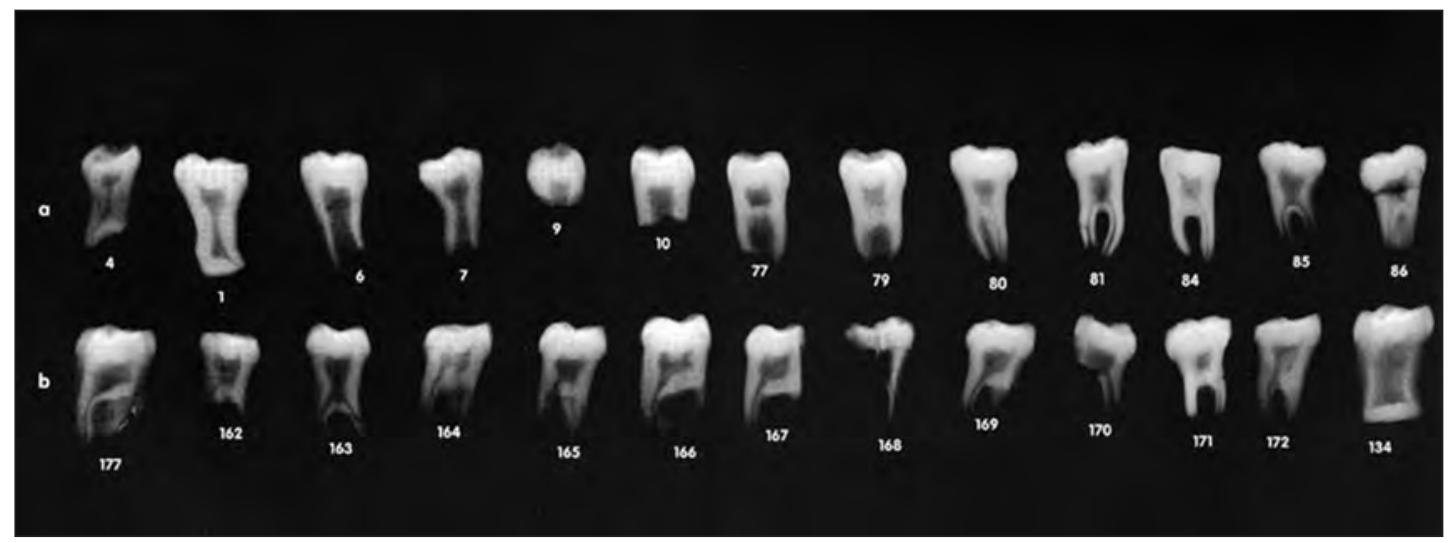

Figure 4 Hypertaurodontism permanent molar teeth of Krapina Neanderthals (7).
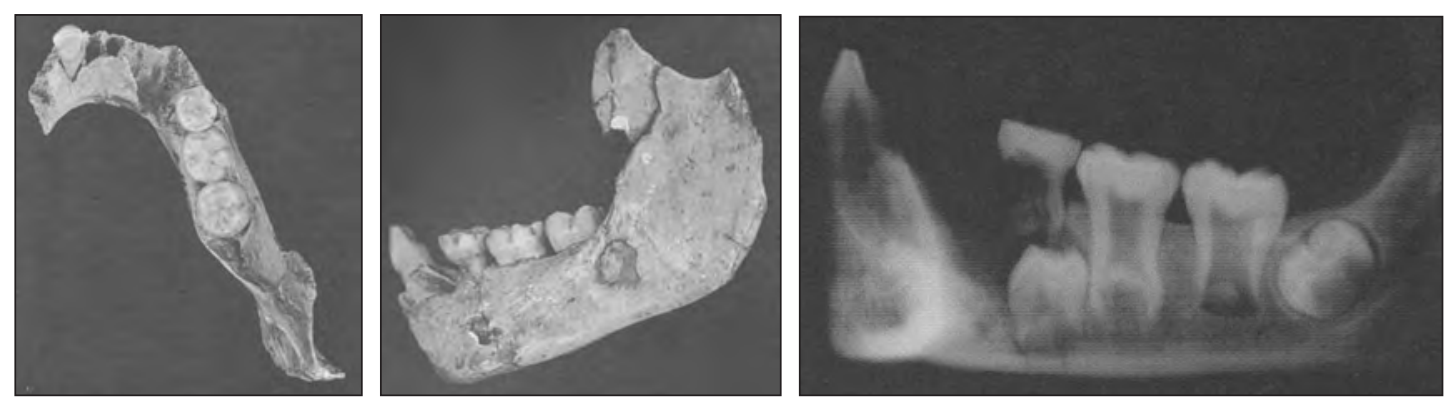

Figure 5 Mandible, age 10-11 years, position crown wisdom tooth $(6,7)$.

present in $1.74 \%, 3.44 \%$ and $11.89 \%$ respectively. When these results for $\mathrm{KN}$ and persons from the $1^{\text {st }}$ century are compared to the results of Brothwell (33), they show very good complementarity (Table 5).

In Brothwell there was no caries diagnosed on 259 teeth of European Neanderthals, just as there was no caries diagnosed on the 281 teeth of the KN. Brothwell indicates the life expectancy of European Neanderthal $70,000-35,000$ years B.C. His results (33) were published in 1963. At that time life expectancy of $\mathrm{KN}$ was determined by radioactive carbon (C-15) and it was considered that KN lived earlier than 40,000 - 30,000 years B.C. but the newer method ESR from 1995, showed that KN lived 130,000 years B.C. (5).

The frequency and distribution of caries in the mediaeval population (34), from the $10^{\text {th }}$ to $11^{\text {th }}$ century in Croatia on a sample of 979 teeth, showed recorded caries as in- terproximal 3.9\% (76 teeth), buccal/lingual $1.3 \%$ (25 teeth), and on the occlusal surfaces of a sample of 645 teeth, caries was found in $2.9 \%$ (19 teeth).

Some specificities of $\mathrm{KN}$ teeth: The term „taurodont" was coined by Arthur Keith 1913 (35) to describe the condition of free roots. Taurodontism is best measured in radiographs and, whilst it may affect all permanent or deciduous cheek teeth, it is most pronounced in molars. The whole dentition may be affected, or just a few teeth $(1,36)$. Taurodontism is prominent amongst the Krapina Neandertal specimens (37-39).

Mandible 53, age 10-11, x-ray findings, if $\mathrm{KN}$ had lived some years more, he would have had the diagnosis - dentitio difficilis (Figure 5).

Like other Neanderthals, the KN teeth showed multiple evidence of manipulations and processing activities in the anterior teeth. The permanent and deciduous teeth 
showed numerous scratches of the incisors and canines, especially in the upper jaws. Out of seven specimens predominantly showing oblique scratches, six exhibited a right-handed pattern. Combined with other Neanderthal data, KN showed the frequency of handedness similar to contemporary humans (40).

\section{Conclusions}

A skeletal study was undertaken on the skulls of $\mathrm{KN}$ and $1^{\text {st }}, 10^{\text {th }}$ and $20^{\text {th }}$ century contemporary man of the connection between alveolar bone resorption and dental caries. Alveolar resorption changes in $\mathrm{KN}$, $1^{\text {st }}, 10^{\text {th }}$ and $20^{\text {th }}$ century human tooth samples were assessed by use of the $\mathrm{TCH}$-index (4). Diagnosis of dental caries was made by inspection and with a dental probe. The results obtained pointed to the following conclusions:

1. Resorption changes were greater on the vestibular than interdental side in all jaws from the four study periods. The greatest resorption of $6.12 \mathrm{~mm}$ was recorded on the vestibular side in the jaws of $\mathrm{KN}$.

2. During evolution, alveolar bone resorption on the vestibular side was in decrease, as differentiated from resorption of the interdental septum, which showed an increasing tendency. In the $\mathrm{KN}$ and $20^{\text {th }}$ century samples, this ratio was 2.38 and 1.23 in the 20-29 years subgroup, respectively, and 1.06 in the $20^{\text {th }}$ century $>50$ year subgroup (Table 2 ).

3. When the ratio of interdental to vestibular (I/V) resorption was expressed as a factor, it was 1.00 in $\mathrm{KN}$ and 1.94 in the $20^{\text {th }}$ century 20-29 year subgroup, and 2.24 in the $>50$ year subgroup (Table 3 ).

4. The dynamics of the two more pronounced resorption patterns of the interdental septum relative to the vestibular side of the alveoli in contemporary man is a consequence of greater plaque depo- sition and its pathogenesis in the interdental space than on the vestibular side.

5. Four samples of teeth from four time periods, i.e. the $\mathrm{KN}$ who reportedly lived over 130,000 years ago showed no caries (281 teeth), whereas the teeth from the $1^{\text {st }}$ century showed $1.74 \%$ caries $(860$ teeth), the $10^{\text {th }}$ century $3.44 \%$ caries (697 teeth) and the $20^{\text {th }}$ century $11.87 \%$ caries (1,741 teeth).

6. These findings have a practical, educational and preventive value for oral hygiene improvement, especially of the interdental space, which should help decrease the prevalence of periodontal disease and dental caries, and improve oral as well as general health.

Authors' contributions: Conception and design: BT and HRK; Acquisition, analysis and interpretation of data: BT and MČS; Drafting the article: BT and MČS; Revising it critically for important intellectual content: BT and MČS.

Conflict of interest: The authors declare that they have no conflict of interest. This article was not sponsored by any external organization.

\section{References}

1. Hillson S. Dental anthropology. Cambridge: University press; 2003.

2. Brothwell DR. Dental anthropology. Oxford-London: Pergamon press; 1963.

3. Kelly MA, Larsen CS. Advances in dental anthropology. New York: Wiley Lis Inc; 1991.

4. Davies DM, Picton DCA, Alexander AG. An objective method of assessing the periodonta condition in human skulls. J Periodont Res. 1969;4:74-7.

5. Rink WJ, Schwartz HP, Smith FH, Radovčić J. ESR ages for Krapina hominids. Nature. 1995;378:24.

6. Radovčić J, Smith FH, Trinkaus E, Wolpoff $\mathrm{MH}$. The Krapina hominides - an illustrated catalog of skeletal collection. Zagreb: Croatian natural history museum - Mladost; 1988.

7. Kricun M, Monge J, Mann A, Finkel G, Lampl M, Radovčić J. The Krapina hominides - a radiographic atlas of the skeletal collection. Zagreb: Croatian natural history museum; 1999. 
8. Martin R, Saller K. Lehrbuch der Anthropologie. Band 2: Kraniologie, Osteologie. Jena: Gustav Fischer Verlag; 1928.

9. R Development Core Team (2008). R: A language and environment for statistical computing. $\mathrm{R}$ Foundation for Statistical Computing, Vienna, Austria. Available from: http://www.R-project.org

10. Goldberg HJ, Weintraub JA, Roghman KJ, Cornwall WS. Measuring periodontal disease in ancient populations: Root and wear indices in study of American Indian skulls. J Periodont. 1976;47:34851.

11. Muller D, Perizonius WR. The scoring of defects of the alveolar process in human crania. J Hum Evol. 1980;9:113-6.

12. Manson Jd, Eley BM. Outline of periodontics. Oxford: Wright; 2000.

13. Severson JA, Moffett BC, Kokoich V, Selipsky H. A histologic study of age changes in the adukts humans periodontal joint (ligament). J Periodontol. 1978;49:189-200.

14. Sarajlić N, Topić B, Brkić H, Alajbeg ŽI. Aging quantification on alveolar bone loss. Coll Anthropol. 2009;33:1165-70.

15. Löe H, Theilade E, Jensen J. Experimental gingivitis in man. J Periodont. 1965;36:177-87.

16. Mandel ID. Summary of conference and perspectives for the future. In: Genco RJ, Mergenhagen $\mathrm{SE}$, editors. Host - parasite interactions in periodontal diseases. Washington, D.C.: American Sosiety for Microbiology; 1988. p. 404-9.

17. Lang NP. The basis for mechanical plaque control. In: Osborne D, Doherty F, editors. The art and science of interdental cleaning. New York - London: The Parthenon publishing group; 1998. p. 15-22.

18. Mc Hugh WD. Dental plaque. Edinbourgh: Livingstone; 1969.

19. Osborne D, Doherty F. The art and science of interdental cleaning. New York - London: The Parthenon publishing group; 1998.

20. Kinane DF. The role of interdental cleaning in primary and secondary prevention. In: Osborne D, Doherty F, editors. The art and science of interdental cleaning. New York - London: The Parthenon publishing group; 1998. p. 23-32.

21. Prato PG, Cattabriga M, Rotundo R. Interdental cleaning for post-periodontal surgery patients and other special groups. In: Osborne D, Doherty F, editors. The art and science of interdental cleaning. New York - London: The Parthenon publishing group; 1998. p. 33-9.

22. Schou L. Behavioural aspects of interdental cleaning. In: Osborne D, Doherty F, editors. The art and science of interdental cleaning. New York - London: The Parthenon publishing group; 1998. p. 41-7.

23. Vialle L. Interdental cleaning - patient motivation and compliance: practical advice and recommendations for the dental hygienist. In: Osborne D, Doherty F, editors. The art and science of interdental cleaning. New York - London: The Parthenon publishing group; 1998. p. 49-57.

24. Lavelle CLB, Moore WJ. Alveolar bone resumption in Anglo-Saxon seventeen mandibles. J Periodont Res. 1969;4:70-3.

25. Kerr NW. The periodontal status of a Scotish mediaeval cohort. J Paleopathol. 1989;2:119-28.

26. Topić B, Cekić-Arambašin A, Jorgić-Srdjak K. Alveolar bone resorption in the skulls. Coll Anthropol. 1998;22(Suppl):117-22.

27. Topić B, Papo A. Alveolar bone resorption in jaws of the Krapina Neandertals. II Internacional conference: “The Krapina Neandertals and human evolution in the Central Europe". August 23-26 1999. Zagreb-Krapina. Book of Abstracts. $1999 ; 46$.

28. Whittaker DK, Molleson T, Daniel AT, Williams JT, Rose P, Resteghini R. Quantitative assessment of tooth wear, alveolar crest height and continuing eruption in a Romano-British population. Arch Oral Biol. 1985;30:493-501.

29. Clarke GN, Hirsch SR. Physiological, pulpal, and periodontal factors influencing alveolar bone. In: Kelley MA, Larsen CS. Advances in Dental anthropology. New York: Wiley-Lis; 1991;241-66.

30. Kerr NW. Prevalence and natural history of periodontal disease in Scotland - the mediaeval period (900 - 1600 AD). Arch Oral Biol. 1991;26:346-54.

31. Kerr NW. Prevalence and natural history of periodontal disease in a London, Spitalfields, population (1645 - 1852 AD). Arch Oral Biol. 1994;29:581-8.

32. Kerr NW. Prevalence and natural history of periodontal disease in prehistoric Scots (pre-900 AD). J Periodont Res. 1998;33:131-7.

33. Brothwell DR. The macroscopic dental pathology of some earlier populations. In: Brothwell DR, editor. Dental anthropology. Oxford-London: Pergamon press; 1963. p. 271-88.

34. Vodanović M, Brkić H, Šlaus M, Demo Ž. The frequency and distribution of caries in the mediaeval population of Bijelo Brdo in Croatia (10-th - 11th century). Arch Oral Biol. 2005;50:669-80.

35. Keith A. Problems relating to the teeth of the ealier forms of prehistoric man. Proc R Soc Med (Odontol sec). 1913;6:103-19. 
36. Konjhodžić-Raščić H, Malokas-Čuvalo J. Taurodontism - exotaurodontism, endotaurodontism. Stomatol Vjes. 1982;11:35-8.

37. Kallay J. Osobitosti zubi krapinskih neandertalaca. In: M. Malez, editor. Krapina 1899-1969. Zagreb: Jugoslavenska akademija znanosti i umjetnosti; 1970. p. 165-76.

38. Kallay J. Dentalna antropologija, Svezak I. Zagreb: Izdavački zavod Jugoslavenske akademije; 1974.

39. Dumančić J, Kaić Z, Brkić H, Petrovečki M. Tooth pulp dimensions and taurodontism in Krapina
Neanderthals. II International conference "The Krapina Neandertals and human evolution in Central Europe". August 23-26 1999. ZagrebKrapina. Book of Abstracts. 1999;21-22.

40. Frayer DW, Fox CL. Labial scratches, dental manipulation and handedness at Krapina. II International conference "The Krapina Neandertals and human evolution in Central Europe”. August 23-26 1999. Zagreb-Krapina. Book of Abstracts.1999;24. 